\title{
A simple electrochemical method for conversion of Pt wires to Pt concave icosahedra and nanocubes on carbon paper for electrocatalytic hydrogen evolution
}

\author{
Zhimin Luo ${ }^{1}$, Chaoliang Tan ${ }^{1}$, Zhuangchai Lai ${ }^{1}$, Xiao Zhang ${ }^{1}$, Junze Chen ${ }^{1}$, Ye Chen ${ }^{1}$, Bo Chen ${ }^{1}$, \\ Yue Gong ${ }^{2}$, Zhicheng Zhang ${ }^{1}$, Xuejun $\mathrm{Wu}^{1}$, Bing $\mathrm{Li}^{3}$, Yun Zong ${ }^{3}$, Lin $\mathrm{Gu}^{2}$ and Hua Zhang ${ }^{1 *}$
}

\begin{abstract}
In the controlled synthesis of noble metal nanostructures using wet-chemical methods, normally, metal salts/complexes are used as precursors, and surfactants/ ligands are used to tune/stabilize the morphology of nanostructures. Here, we develop a facile electrochemical method to directly convert Pt wires to Pt concave icosahedra and nanocubes on carbon paper through the linear sweep voltammetry in a classic three-electrode electrochemical cell. The Pt wire, carbon paper and $\mathrm{Ag} / \mathrm{AgCl}\left(3 \mathrm{~mol} \mathrm{~L}^{-1} \mathrm{KCl}\right)$ are used as the counter, working and reference electrodes, respectively. Impressively, the formed Pt nanostructures exhibit better electrocatalytic activity towards the hydrogen evolution compared to the commercial $\mathrm{Pt} / \mathrm{C}$ catalyst. This work provides a simple and effective way for direct conversion of $\mathrm{Pt}$ wires into well-defined Pt nanocrystals with clean surface. We believe it can also be used for preparation of other metal nanocrystals, such as $\mathrm{Au}$ and Pd, from their bulk materials, which could exhibit various promising applications.
\end{abstract}

Keywords: noble metals, electrochemical conversion, concave nanostructures, electrocatalysis, hydrogen evolution

\section{INTRODUCTION}

Noble metals including Pt have been widely used for energy storage and conversion because of their excellent electrocatalytic activity towards the hydrogen evolution, and the oxygen reduction and evolution [1-7]. Due to the scarcity and high cost of noble metals, improvement of their utilization efficiency becomes extremely important. The catalytic performance of noble metal nanocrystals is highly dependent on their size, shape, composition, crystal facet, crystal phase, etc. Besides the recently de- veloped crystal-phase controlled synthesis of noble metal nanocrystals [8-13], lots of efforts have been devoted into the shape-controlled synthesis of noble metal nanostructures with high-index facets [14-22]. However, most of the reported noble metal nanostructures with unique morphologies are prepared via the traditional wet-chemical methods in which metal salts or complexes are used as precursors, and surfactants or ligands are used to tune/ stabilize their morphologies [23-27]. Until now, to the best of our knowledge, there is no report on direct preparation of noble metal nanocrystals with controlled morphologies and clean surfaces in solution from their bulk materials.

As known, electrochemical synthesis is one of the simple and efficient methods for preparing noble metal nanostructures [28]. In order to control the morphology of noble metal nanostructures using the electrochemical method, anodic aluminum oxide membranes or mesoporous silicon templates are normally used [29-32]. However, further process is required to remove these templates in order to purify noble metal nanomaterials used for various applications including electrocatalysis. Recently, Sun and co-workers [14,17,33-35] developed a square-wave potential based method to directly synthesize Pt and Pd polyhedra with high-index facets on glassy carbon electrode (GCE) using noble metal salts, i.e., $\mathrm{K}_{2} \mathrm{PtCl}_{6}$ and $\mathrm{PdCl}_{2}$, respectively, as precursors.

In this study, different from previously reported methods, we develop a facile electrochemical method for preparation of $\mathrm{Pt}$ concave icosahedra and nanocubes from Pt wire. As shown in Scheme 1, the electrochemical synthesis of $\mathrm{Pt}$ concave icosahedra and nanocubes can be

${ }^{1}$ Center for Programmable Materials, School of Materials Science and Engineering, Nanyang Technological University, Singapore 639798, Singapore

${ }^{2}$ Beijing National Laboratory for Condensed Matter Physics, Institute of Physics, Chinese Academy of Sciences, Beijing 100190, China

${ }^{3}$ Institute of Materials Research and Engineering, A*STAR (Agency for Science, Technology and Research), Singapore 138634, Singapore

"Corresponding author (email: hzhang@ntu.edu.sg, hzhang166@gmail.com) 


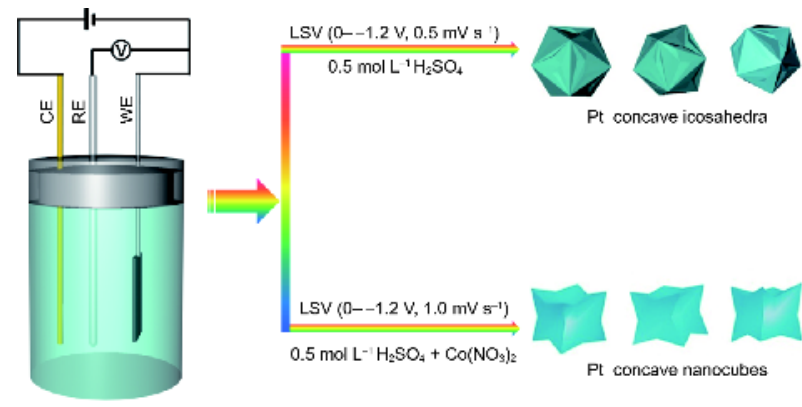

Scheme 1 Schematic illustration of electrochemical setup for conversion of $\mathrm{Pt}$ wire into $\mathrm{Pt}$ concave icosahedra and nanocubes on carbon paper. $\mathrm{CE}$ : Pt wire; $\mathrm{RE}: \mathrm{Ag} / \mathrm{AgCl}\left(3 \mathrm{~mol} \mathrm{~L}^{-1} \mathrm{KCl}\right)$; WE: carbon paper.

achieved in a three-electrode electrochemical cell with carbon paper, $\mathrm{Ag} / \mathrm{AgCl}\left(3 \mathrm{~mol} \mathrm{~L}^{-1} \mathrm{KCl}\right)$ and $\mathrm{Pt}$ wire as working electrode (WE), reference electrode (RE) and counter electrode (CE), respectively. Linear sweep voltammetry (LSV) scanning was carried out to directly convert the Pt wire into $\mathrm{Pt}$ concave icosahedra on carbon paper in $0.5 \mathrm{~mol} \mathrm{~L}^{-1} \mathrm{H}_{2} \mathrm{SO}_{4}$ aqueous solution. When cobalt nitrate was added in the aforementioned electrochemical synthesis solution, Pt concave nanocubes were obtained. Note that no surfactants or ligands were used in the aforementioned reactions. Therefore, the surface of obtained Pt nanostructures is clean. As a proof-of-concept application, the Pt concave icosahedra and nanocubes on carbon paper were used as electrocatalysts for the hydrogen evolution reaction (HER), which exhibited higher electrocatalytic activity in $0.5 \mathrm{~mol} \mathrm{~L}^{-1} \mathrm{H}_{2} \mathrm{SO}_{4}$ aqueous solution compared to the commercial $\mathrm{Pt} / \mathrm{C}$ catalyst.

\section{EXPERIMENTAL SECTION}

\section{Materials}

$\mathrm{Pt}$ wires were purchased from the $\mathrm{CH}$ Instruments Ins. $\mathrm{HClO}_{4}, \mathrm{H}_{2} \mathrm{SO}_{4}$ and $\mathrm{Co}\left(\mathrm{NO}_{3}\right)_{2} \cdot 6 \mathrm{H}_{2} \mathrm{O}$ were purchased from Sigma-Aldrich (Saint Louis, Missouri, USA). Milli-Q water (Millipore, $18.2 \mathrm{M} \Omega \mathrm{cm}$ ) was used in all experiments.

\section{Preparation of Pt concave icosahedra and nanocubes from Pt wires}

Pt concave icosahedra were prepared in $10.0 \mathrm{~mL}$ of $0.5 \mathrm{~mol} \mathrm{~L}^{-1} \mathrm{H}_{2} \mathrm{SO}_{4}$ solution by repeated LSV scanning ( 25 times) from 0 to $-1.2 \mathrm{~V}\left(v s\right.$. $\left.\mathrm{Ag} / \mathrm{AgCl}\left(3 \mathrm{~mol} \mathrm{~L}^{-1} \mathrm{KCl}\right)\right)$ at scan rate of $0.5 \mathrm{mV} \mathrm{s}^{-1}$ using a three-electrode electrochemical cell with carbon paper as the $\mathrm{WE}, \mathrm{Ag} / \mathrm{AgCl}$ $\left(3 \mathrm{~mol} \mathrm{~L}^{-1} \mathrm{KCl}\right)$ as the $\mathrm{RE}$, and $\mathrm{Pt}$ wire as the $\mathrm{CE}$. Pt concave nanocubes were prepared on carbon paper by repeated LSV scanning ( 25 times) from 0 to $-1.2 \mathrm{~V}$ ( $v s$. $\left.\mathrm{Ag} / \mathrm{AgCl}\left(3 \mathrm{~mol} \mathrm{~L}^{-1} \mathrm{KCl}\right)\right)$ at scan rate of $1.0 \mathrm{mV} \mathrm{s}^{-1}$ after adding $100 \mu \mathrm{L}$ of cobalt nitrate $\left(3 \mathrm{mmol} \mathrm{L}^{-1}\right)$ into the aforementioned $10 \mathrm{~mL}$ of $0.5 \mathrm{~mol} \mathrm{~L}^{-1} \quad \mathrm{H}_{2} \mathrm{SO}_{4}$ aqueous solution.

\section{Electrocatalytic hydrogen evolution of Pt concave icosahedra and nanocubes}

Pt concave icosahedra or Pt concave nanocubes on carbon paper were directly used as the WE to evaluate their electrocatalytic activity for hydrogen evolution reaction (HER). The amount of Pt of the prepared Pt concave icosahedra and nanocubes was measured by the inductive coupled plasma-optical emission spectroscopy (ICPOES). Electrochemical active surface areas (ECSAs) of Pt concave icosahedra and nanocubes on carbon paper were evaluated by cyclic voltammetry $(\mathrm{CV})$ in $\mathrm{N}_{2}$-saturated $0.5 \mathrm{~mol} \mathrm{~L}^{-1} \mathrm{H}_{2} \mathrm{SO}_{4}$ aqueous solution at scan rate of $50 \mathrm{mV} \mathrm{s}^{-1}$. ECSA $=Q_{\mathrm{H}} /(m \times 210)$, where $Q_{\mathrm{H}}(\mu \mathrm{C})$ is the charge of hydrogen absorption on catalysts, $210\left(\mu \mathrm{C} \mathrm{cm}^{-2}\right)$ is the charge associated with monolayer adsorption of hydrogen on the surface of $\mathrm{Pt}$, and $m(\mathrm{~g})$ is the loading amount of $\mathrm{Pt}$ per $\mathrm{cm}^{2}$ geometric area of electrode. HER measurements were carried out in $\mathrm{H}_{2}$ saturated $0.5 \mathrm{~mol} \mathrm{~L}^{-1} \mathrm{H}_{2} \mathrm{SO}_{4}$ aqueous solution by LSV method at scan rate of $5 \mathrm{mV} \mathrm{s}^{-1}$ using $\mathrm{Ag} / \mathrm{AgCl}$ $\left(3 \mathrm{~mol} \mathrm{~L}^{-1} \mathrm{KCl}\right)$ and graphite rod as $\mathrm{RE}$ and $\mathrm{CE}$, respectively. As a comparison, the commercial $\mathrm{Pt} / \mathrm{C}$ suspension with the same amount of Pt loading as Pt concave icosahedra or Pt concave nanocubes was dropped onto carbon paper for CV and LSV measurements. The $\mathrm{Ag} /$ $\mathrm{AgCl}\left(3 \mathrm{~mol} \mathrm{~L}^{-1} \mathrm{KCl}\right)$ electrode was calibrated with respect to the reversible hydrogen electrode (RHE) in the $\mathrm{H}_{2}$-saturated $0.5 \mathrm{~mol} \mathrm{~L}^{-1} \mathrm{H}_{2} \mathrm{SO}_{4}$ aqueous solution. As shown in Fig. S1, $E$ (vs. RHE) $=E(v s . \mathrm{Ag} / \mathrm{AgCl}$ $\left.\left(3 \mathrm{~mol} \mathrm{~L}^{-1} \mathrm{KCl}\right)\right)+0.246 \mathrm{~V}$.

\section{Characterization}

Pt concave icosahedra and nanocubes on carbon paper were directly used for scanning electron microscopy (SEM, JSM-7600F, JEOL). Samples for transmission electron microscopy (TEM) and high-resolution TEM (HRTEM) (JEOL JEM-2100F) characterizations were prepared by sonicating carbon paper-supported Pt concave icosahedra or nanocubes in ethanol and then dropping the formed Pt concave icosahedron or nanocube ethanol suspension on copper grids, which were dried at room temperature. X-ray photoelectron spectroscopy (XPS) measurements were performed on a XPS spectrometer (QUANTUM 2000, Physical electronics, 

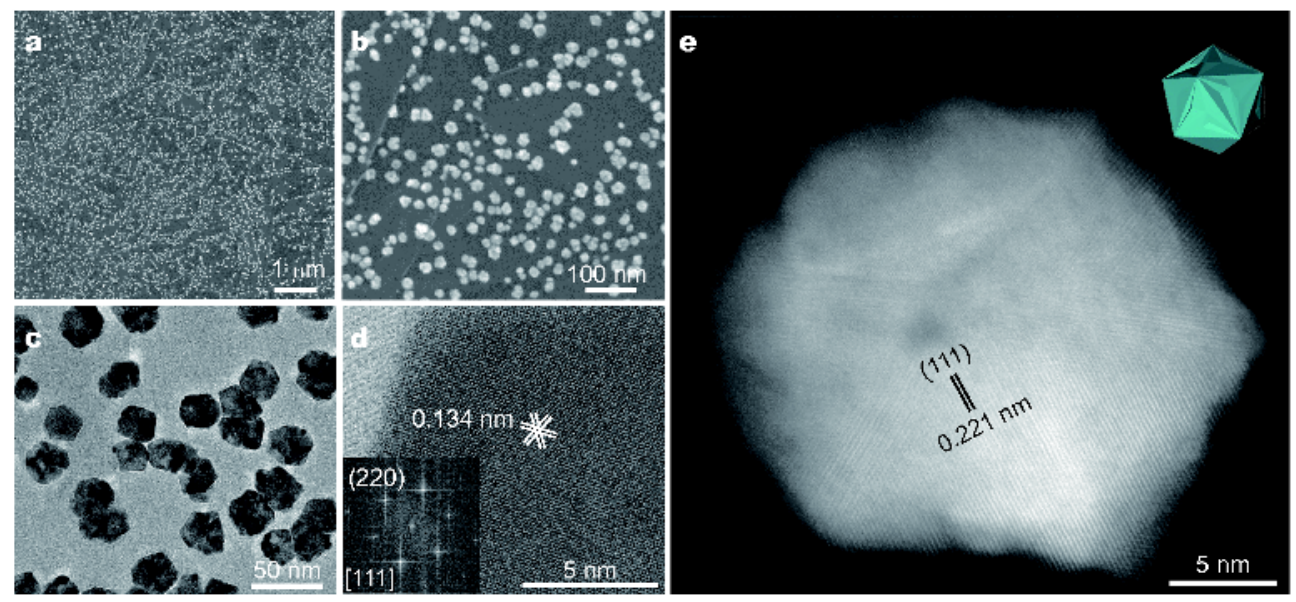

Figure 1 ( $a, b)$ SEM images of the formed Pt concave icosahedra on carbon paper. (c) TEM and (d) HRTEM images of the formed Pt concave icosahedra. Inset: The corresponding fast fourier transform (FFT) pattern of the Pt concave icosahedron in (d). (e) HAADF-STEM image taken from a typical Pt concave icosahedron along a five-fold symmetry axis. Inset: 3D model of a Pt concave icosahedron.

USA) using a monochromatic $\mathrm{Al} \mathrm{Ka}$ as the X-ray source. The binding energies were calibrated by the $\mathrm{C} 1 \mathrm{~s}$ peak at $284.6 \mathrm{eV}$. ICP-OES was performed on a Dual-view Optima 5300 DV ICP-OES system to determine the amount of Pt element of the prepared Pt concave icosahedra and nanocubes on carbon paper.

\section{RESULTS AND DISCUSSION}

As shown in Scheme 1, Pt concave icosahedra were formed on carbon paper through the repeated LSV scanning (25 times) from 0 to $-1.2 \mathrm{~V}$ ( $v s . \mathrm{Ag} / \mathrm{AgCl}$ $\left(3 \mathrm{~mol} \mathrm{~L}^{-1} \mathrm{KCl}\right)$ ) at scan rate of $0.5 \mathrm{mV} \mathrm{s}^{-1}$ in $10 \mathrm{~mL}$ of $0.5 \mathrm{~mol} \mathrm{~L}^{-1} \mathrm{H}_{2} \mathrm{SO}_{4}$ aqueous solution. The obtained $\mathrm{Pt}$ concave icosahedra were characterized by SEM, TEM, HRTEM and XPS. As shown in Fig. 1a, b, most of Pt concave icosahedra are highly dispersed on carbon paper with the size of $21.5 \pm 7.9 \mathrm{~nm}$ (Fig. S2 in Supplementary information). TEM image (Fig. 1c) shows the concave icosahedral shape of Pt nanocrystals. HRTEM image (Fig. 1d) of a single Pt concave polyhedron displays the lattice fringes with interplanar spacing of about $0.134 \mathrm{~nm}$ along the [111] zone axis (Fig. 1d, inset), corresponding to the (220) plane of face-centered-cubic (fcc) Pt [36]. The characteristic five-fold symmetry axe of Pt concave icosahedron with the exposed (111) plane is observed from a high-angle annular dark-field scanning TEM (HAADFSTEM) image (Fig. 1e), which matches well with the three-dimensional (3D) model of icosahedron (inset in Fig. 1e) [37-41]. The XPS survey spectrum of Pt concave icosahedra (Fig. S3a) shows the characteristic peak of Pt at $68-77 \mathrm{eV}$. High-resolution Pt $4 \mathrm{f}$ XPS spectrum of $\mathrm{Pt}$ concave icosahedra (Fig. S3b) shows two peaks at 71.2 and $74.4 \mathrm{eV}$, corresponding to $\mathrm{Pt} 4 \mathrm{f}_{7 / 2}$ and $\mathrm{Pt} 4 \mathrm{f}_{5 / 2}$ of zerovalent $\mathrm{Pt}$, respectively [42].

Interestingly, after adding $100 \mu \mathrm{L}$ of cobalt nitrate $\left(3 \mathrm{mmol} \mathrm{L}^{-1}\right)$ into the aforementioned $10 \mathrm{~mL}$ of $0.5 \mathrm{~mol} \mathrm{~L}^{-1} \mathrm{H}_{2} \mathrm{SO}_{4}$ aqueous solution, Pt concave nanocubes were formed on carbon paper by the repeated LSV scanning (25 times) from 0 to $-1.2 \mathrm{~V}$ (vs. $\mathrm{Ag} / \mathrm{AgCl}$ $\left.\left(3 \mathrm{~mol} \mathrm{~L}^{-1} \mathrm{KCl}\right)\right)$ at scan rate of $1.0 \mathrm{mV} \mathrm{s}^{-1}$. As shown in Fig. 2a, b, well-dispersed Pt concave nanocubes with the size of $22.6 \pm 7.4 \mathrm{~nm}$ (Fig. S4) can be observed. TEM image (Fig. 2c) displays the shape of $\mathrm{Pt}$ concave nanocubes. HRTEM image (Fig. 2d) of a single Pt concave nanocube presents the lattice fringes with interplanar spacing of $0.196 \mathrm{~nm}$ along the [100] zone axis (Fig. 2d, inset), corresponding to the (200) plane of fcc Pt [15]. A HAADFSTEM image shows the shape of typical Pt concave nanocube with the exposed (200) plane (Fig. 2e), matching very well with its $3 \mathrm{D}$ model (inset in Fig. 2e). Moreover, the XPS survey spectrum of Pt concave nanocubes (Fig. $\mathrm{S} 5 \mathrm{a})$ shows the characteristic peak of $\mathrm{Pt}$, and no peak ascribed to Co is observed, indicating the formation of pure Pt nanostructures. In the high-resolution Pt $4 \mathrm{f} \mathrm{XPS}$ spectrum of $\mathrm{Pt}$ concave nanocubes (Fig. S5b), two peaks at 71.2 and $74.5 \mathrm{eV}$, assignable to $\mathrm{Pt} 4 \mathrm{f}_{7 / 2}$ and $\mathrm{Pt} 4 \mathrm{f}_{5 / 2}$ of zero-valent $\mathrm{Pt}$, respectively, are observed [42].

Noble metal concave nanostructures have been proven to be highly active catalysts for electrocatalysis, such as oxygen reduction reaction [18], electrochemical oxidation of ethanol [43] and formic acid [16], and HER [44]. In this work, as a proof-of-concept application, Pt concave 


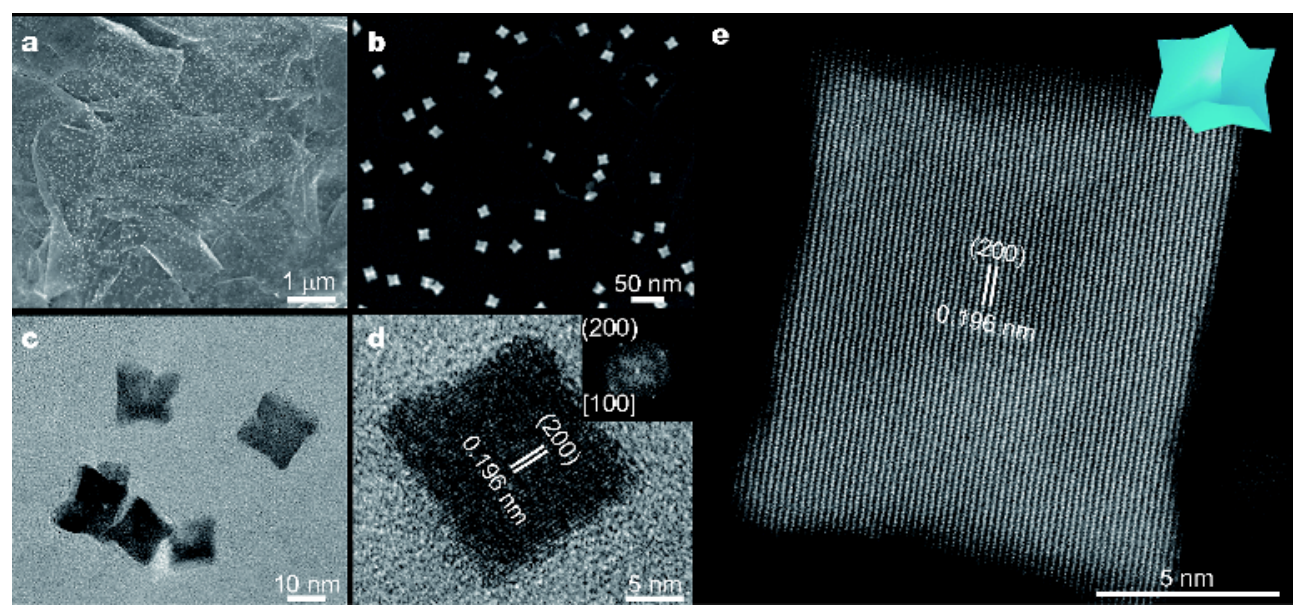

Figure 2 (a, b) SEM images of the formed Pt concave nanocubes on carbon paper. (c) TEM and (d) HRTEM images of the formed Pt concave nanocubes. Inset: The corresponding FFT pattern of Pt concave nanocube in (d). (e) HAADF-STEM image of a typical Pt concave nanocube. Inset: 3D model of a Pt concave nanocube.

icosahedra and nanocubes on carbon paper are used as highly efficient electrocatalysts for hydrogen evolution due to their exposed active facets and clean surface. The commercial $\mathrm{Pt} / \mathrm{C}$ catalyst is used for comparison. ECSAs of $\mathrm{Pt} / \mathrm{C}$, and $\mathrm{Pt}$ concave icosahedra and nanocubes were evaluated by their $\mathrm{CV}$ curves in $\mathrm{N}_{2}$-saturated $0.5 \mathrm{~mol} \mathrm{~L}^{-1}$ $\mathrm{H}_{2} \mathrm{SO}_{4}$ aqueous solution (Fig. 3a), As shown in Fig. 3b, the ECSAs of Pt concave icosahedra $\left(107.5 \mathrm{~m}^{2} \mathrm{~g}^{-1}\right)$ and $\mathrm{Pt}$ concave nanocubes $\left(134.9 \mathrm{~m}^{2} \mathrm{~g}^{-1}\right)$ are much greater than that of $\mathrm{Pt} / \mathrm{C}\left(34.1 \mathrm{~m}^{2} \mathrm{~g}^{-1}\right)$. Polarization curves of $\mathrm{Pt} / \mathrm{C}, \mathrm{Pt}$ concave icosahedra and nanocubes are shown in Fig. 3c, indicating that $\mathrm{Pt}$ concave icosahedra and nanocubes give better electrocatalytic activity towards hydrogen evolution compared to the commercial Pt/C catalyst. As shown in Fig. $3 \mathrm{~d}$, the mass activities of $\mathrm{Pt}$ concave icosahedra

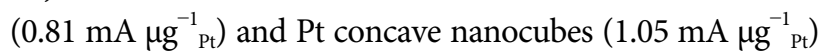
for electrochemical hydrogen evolutionat working potential of $-0.05 \mathrm{~V}$ ( $v s$. RHE) are about 2.3 and 2.9 times that of commercial $\mathrm{Pt} / \mathrm{C}$ catalyst $\left(0.36 \mathrm{~mA} \mu \mathrm{g}_{\mathrm{Pt}}^{-1}\right)$, respectively. All the aforementioned results confirm that the Pt concave icosahedra and nanocubes synthesized by our electrochemical method have higher electrocatalytic activities for HER compared to the commercial $\mathrm{Pt} / \mathrm{C}$ catalyst. Furthermore, the durability tests show that the commercial $\mathrm{Pt} / \mathrm{C}$ showed $9.2 \%$ decrease of current density for HER at $-0.1 \mathrm{~V}(v \boldsymbol{s}$. RHE) after 20,000 potential cycles from 0.248 to $-0.152 \mathrm{~V}$ in $\mathrm{H}_{2}$-saturated $0.5 \mathrm{~mol} \mathrm{~L}^{-1} \mathrm{H}_{2} \mathrm{SO}_{4}$ aqueous solution (Fig. S6a), while the polarization curves of Pt concave icosahedra and nanocubes for HER display no obvious change after 20,000 potential cycles (Fig. S6b, c), indicating the better electrocatalytic stabilities of $\mathrm{Pt}$ concave icosahedra and nanocubes compared to the commercial Pt/C.

The superior electrocatalytic activities of $\mathrm{Pt}$ concave icosahedra and nanocubes for HER might arise from their concave and stepped surface morphologies, exposed highactive facets, no surfactants or ligands on the Pt surface, and good contact between the prepared Pt nanostructures and carbon paper. First, Pt concave icosahedra and nanocubes present atomic steps and kinks with low coordination numbers, which have been proved to be beneficial for electrocatalysis such as hydrogen adsorption and evolution [45-47]. Second, small Pt nanoparticles on the commercial $\mathrm{Pt} / \mathrm{C}$ catalyst are usually enclosed by (200) and dominant (111) facets (Fig. S7) [48], while the Pt concave icosahedra and nanocubes possess high-index facets exposed on their surface $[45,47]$, which are more active for hydrogen evolution than the (111) facet $[49,50]$, resulting in the better electrocatalytic HER activity of Pt concave icosahedra and nanocubes compared to the commercial Pt/C. Third, the directly electrodeposited $\mathrm{Pt}$ concave icosahedra and nanocubes on carbon paper are free of surfactants and ligands. Their clean surfaces and good contact with carbon paper result in the easier hydrogen adsorption and electron transfer in the process of HER [14,33].

\section{CONCLUSIONS}

In conclusion, a simple electrochemical method has been developed for conversion of $\mathrm{Pt}$ wires to $\mathrm{Pt}$ concave icosahedra and nanocubes on carbon paper in a classic three-electrode electrochemical system, in which Pt wire, 

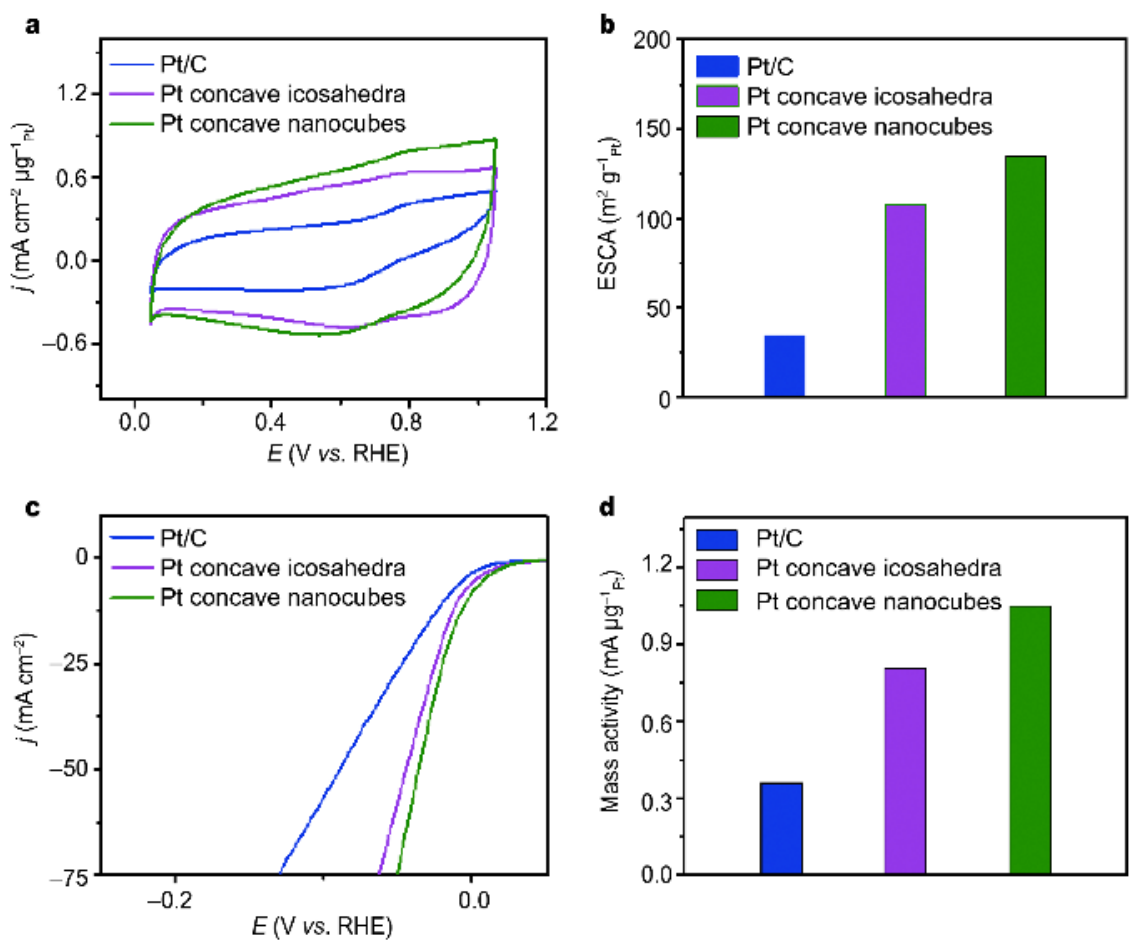

Figure 3 (a) Cyclic voltammetry curves of $\mathrm{Pt} / \mathrm{C}$, and $\mathrm{Pt}$ concave icosahedra and nanocubes on carbon paper in $\mathrm{N}_{2}$-saturated 0.5 mol L $\mathrm{L}^{-1} \mathrm{H}_{2} \mathrm{SO}_{4}$ aqueous solution at scan rate of $50 \mathrm{mV} \mathrm{s}^{-1}$. (b) ECSAs of Pt/C, and Pt concave icosahedra and nanocubes on carbon paper. (c) Polarization curves of $\mathrm{Pt} / \mathrm{C}$, and Pt concave icosahedra and nanocubes for electrocatalytic hydrogen evolution in $\mathrm{H}_{2}$-saturated $0.5 \mathrm{~mol} \mathrm{~L}^{-1} \mathrm{H}_{2} \mathrm{SO}_{4}$ aqueous solution. (d) The mass activities of $\mathrm{Pt} / \mathrm{C}$, and $\mathrm{Pt}$ concave icosahedra and nanocubes for electrocatalytic hydrogen evolution at working potential of $-0.05 \mathrm{~V}(v s$. RHE).

carbon paper and $\mathrm{Ag} / \mathrm{AgCl}\left(3 \mathrm{~mol} \mathrm{~L}^{-1} \mathrm{KCl}\right)$ are used as the counter, working and reference electrodes, respectively. The surface of as-prepared high-active Pt concave icosahedra and nanocubes is clean since no surfactants or ligands were used in the synthesis process. The prepared Pt concave icosahedra and nanocubes on carbon paper used as electrocatalysts for HER show better electrocatalytic activity in comparison with the commercial Pt/C catalyst. Our simple method provides a new and effective way to directly convert $\mathrm{Pt}$ wire into well-defined $\mathrm{Pt}$ nanocrystals for highly efficient electrocatalysis, which might be further used to prepare well-defined nanocrystals (unpublished results), such as $\mathrm{Au}, \mathrm{Pd}, \mathrm{Rh}, \mathrm{Ru}$ and $\mathrm{Cu}$, from their bulk metals for various applications.

Received 8 April 2018; accepted 21 June 2018;

published online 19 July 2018

1 Joo SH, Park JY, Tsung CK, et al. Thermally stable Pt/mesoporous silica core-shell nanocatalysts for high-temperature reactions. Nat Mater, 2009, 8: 126-131

2 Li Y, Cox JT, Zhang B. Electrochemical responses and electrocatalysis at single Au nanoparticles. J Am Chem Soc, 2010, 132: 3047-3054
3 Wang C, Daimon H, Lee Y, et al. Synthesis of monodisperse Pt nanocubes and their enhanced catalysis for oxygen reduction. J Am Chem Soc, 2007, 129: 6974-6975

4 Xia Y, Yang X. Toward cost-effective and sustainable use of precious metals in heterogeneous catalysts. Acc Chem Res, 2017, 50: $450-454$

5 Xiao L, Zhuang L, Liu Y, et al. Activating Pd by morphology tailoring for oxygen reduction. J Am Chem Soc, 2009, 131: 602608

6 Xu C, Wang H, Shen P, et al. Highly ordered Pd nanowire arrays as effective electrocatalysts for ethanol oxidation in direct alcohol fuel cells. Adv Mater, 2007, 19: 4256-4259

7 Zhu W, Michalsky R, Metin Ö, et al. Monodisperse Au nanoparticles for selective electrocatalytic reduction of $\mathrm{CO}_{2}$ to $\mathrm{CO}$. J Am Chem Soc, 2013, 135: 16833-16836

8 Huang X, Li S, Huang Y, et al. Synthesis of hexagonal close-packed gold nanostructures. Nat Commun, 2011, 2: 292

9 Fan Z, Bosman M, Huang X, et al. Stabilization of $4 \mathrm{H}$ hexagonal phase in gold nanoribbons. Nat Commun, 2015, 6: 7684

10 Fan Z, Huang X, Han Y, et al. Surface modification-induced phase transformation of hexagonal close-packed gold square sheets. Nat Commun, 2015, 6: 6571

11 Fan Z, Luo Z, Chen Y, et al. Synthesis of $4 \mathrm{H} / f c c-A u @ M(M=I r$, Os, IrOs) core-shell nanoribbons for electrocatalytic oxygen evolution reaction. Small, 2016, 12: 3908-3913

12 Fan Z, Luo Z, Huang X, et al. Synthesis of $4 \mathrm{H} / f c c$ noble multimetallic nanoribbons for electrocatalytic hydrogen evolution re- 
action. J Am Chem Soc, 2016, 138: 1414-1419

13 Fan Z, Zhang H. Crystal phase-controlled synthesis, properties and applications of noble metal nanomaterials. Chem Soc Rev, 2016, 45: $63-82$

14 Tian N, Zhou ZY, Sun SG, et al. Synthesis of tetrahexahedral platinum nanocrystals with high-index facets and high electrooxidation activity. Science, 2007, 316: 732-735

15 Schrinner M, Ballauff M, Talmon Y, et al. Single nanocrystals of platinum prepared by partial dissolution of Au-Pt nanoalloys. Science, 2009, 323: 617-620

16 Jin $\mathrm{M}$, Zhang $\mathrm{H}$, Xie Z, et al. Palladium concave nanocubes with high-index facets and their enhanced catalytic properties. Angew Chem Int Ed, 2011, 50: 7850-7854

17 Wei L, Fan YJ, Tian N, et al. Electrochemically shape-controlled synthesis in deep eutectic solvents-a new route to prepare Pt nanocrystals enclosed by high-index facets with high catalytic activity. J Phys Chem C, 2012, 116: 2040-2044

18 Yu T, Kim DY, Zhang H, et al. Platinum concave nanocubes with high-index facets and their enhanced activity for oxygen reduction reaction. Angew Chem Int Ed, 2011, 50: 2773-2777

19 Xiao J, Liu S, Tian N, et al. Synthesis of convex hexoctahedral Pt micro/nanocrystals with high-index facets and electrochemistrymediated shape evolution. J Am Chem Soc, 2013, 135: 1875418757

20 Zhang Z, Liu Y, Chen B, et al. Submonolayered Ru deposited on ultrathin $\mathrm{Pd}$ nanosheets used for enhanced catalytic applications. Adv Mater, 2016, 28: 10282-10286

21 Zhang Z, Luo Z, Chen B, et al. One-pot synthesis of highly anisotropic five-fold-twinned ptcu nanoframes used as a bifunctional electrocatalyst for oxygen reduction and methanol oxidation. Adv Mater, 2016, 28: 8712-8717

22 Zhang L, Han L, Liu H, et al. Potential-cycling synthesis of single platinum atoms for efficient hydrogen evolution in neutral media. Angew Chem Int Ed, 2017, 56: 13694-13698

23 Huang X, Zhao Z, Fan J, et al. Amine-assisted synthesis of concave polyhedral platinum nanocrystals having $\{411\}$ high-index facets. J Am Chem Soc, 2011, 133: 4718-4721

24 Kim D, Lee YW, Lee SB, et al. Convex polyhedral Au@Pd coreshell nanocrystals with high-index facets. Angew Chem Int Ed, 2012, 51: 159-163

$25 \operatorname{Lim}$ B, Lu X, Jiang M, et al. Facile synthesis of highly faceted multioctahedral Pt nanocrystals through controlled overgrowth. Nano Lett, 2008, 8: 4043-4047

26 Stamenkovic VR, Fowler B, Mun BS, et al. Improved oxygen reduction activity on $\mathrm{Pt}_{3} \mathrm{Ni}(111)$ via increased surface site availability. Science, 2007, 315: 493-497

27 Zhang L, Zhang J, Kuang Q, et al. $\mathrm{Cu}^{2+}$-assisted synthesis of hexoctahedral Au-Pd alloy nanocrystals with high-index facets. J Am Chem Soc, 2011, 133: 17114-17117

28 Li GR, Xu H, Lu XF, et al. Electrochemical synthesis of nanostructured materials for electrochemical energy conversion and storage. Nanoscale, 2013, 5: 4056-4069

29 Wang D, Zhou WL, McCaughy BF, et al. Electrodeposition of metallic nanowire thin films using mesoporous silica templates. Adv Mater, 2003, 15: 130-133

30 Lee W, Scholz R, Nielsch K, et al. A template-based electrochemical method for the synthesis of multisegmented metallic nanotubes. Angew Chem Int Ed, 2005, 44: 6050-6054

31 Keilbach A, Moses J, Kohn R, et al. Electrodeposition of copper and silver nanowires in hierarchical mesoporous silica/anodic alumina nanostructures. Chem Mater, 2010, 22: 5430-5436

32 Kanno Y, Suzuki T, Yamauchi Y, et al. Preparation of Au nanowire films by electrodeposition using mesoporous silica films as a template: vital effect of vertically oriented mesopores on a substrate. J Phys Chem C, 2012, 116: 24672-24680

33 Tian N, Zhou ZY, Sun SG. Electrochemical preparation of Pd nanorods with high-index facets. Chem Commun, 2009, 293: 1502-1504

34 Zhou ZY, Huang ZZ, Chen DJ, et al. High-Index faceted platinum nanocrystals supported on carbon black as highly efficient catalysts for ethanol electrooxidation. Angew Chem Int Ed, 2010, 49: 411414

35 Liu S, Tian N, Xie AY, et al. Electrochemically seed-mediated synthesis of sub-10 nm tetrahexahedral Pt nanocrystals supported on graphene with improved catalytic performance. J Am Chem Soc, 2016, 138: 5753-5756

36 Yang Y, Jin H, Kim HY, et al. Ternary dendritic nanowires as highly active and stable multifunctional electrocatalysts. Nanoscale, 2016, 8: 15167-15172

37 Wu J, Qi L, You H, et al. Icosahedral platinum alloy nanocrystals with enhanced electrocatalytic activities. J Am Chem Soc, 2012, 134: 11880-11883

38 Zhou W, Wu J, Yang H. Highly uniform platinum icosahedra made by hot injection-assisted GRAILS method. Nano Lett, 2013, 13: 2870-2874

39 Wang X, Choi SI, Roling LT, et al. Palladium-platinum core-shell icosahedra with substantially enhanced activity and durability towards oxygen reduction. Nat Commun, 2015, 6: 7594

40 He DS, He D, Wang J, et al. Ultrathin icosahedral Pt-enriched nanocage with excellent oxygen reduction reaction activity. J Am Chem Soc, 2016, 138: 1494-1497

41 Wang H, Zhou S, Gilroy KD, et al. Icosahedral nanocrystals of noble metals: Synthesis and applications. Nano Today, 2017, 15: 121-144

42 Tang Q, Zhang H, Meng Y, et al. Dissolution engineering of platinum alloy counter electrodes in dye-sensitized solar cells. Angew Chem Int Ed, 2015, 54: 11448-11452

43 Lu CL, Prasad KS, Wu HL, et al. Au nanocube-directed fabrication of $\mathrm{Au}-\mathrm{Pd}$ core-shell nanocrystals with tetrahexahedral, concave octahedral, and octahedral structures and their electrocatalytic activity. J Am Chem Soc, 2010, 132: 14546-14553

44 Wang S, Yang G, Yang S. Pt-frame@Ni quasi core-shell concave octahedral $\mathrm{PtNi}_{3}$ bimetallic nanocrystals for electrocatalytic methanol oxidation and hydrogen evolution. J Phys Chem C, 2015, 119: 27938-27945

45 Zhang $\mathrm{H}$, Jin $\mathrm{M}$, Xia Y. Noble-metal nanocrystals with concave surfaces: synthesis and applications. Angew Chem Int Ed, 2012, 51: 7656-7673

46 Lv H, Xi Z, Chen Z, et al. A new core/shell NiAu/Au nanoparticle catalyst with pt-like activity for hydrogen evolution reaction. J Am Chem Soc, 2015, 137: 5859-5862

47 Zhang Z, Hui J, Liu ZC, et al. Glycine-mediated syntheses of Pt concave nanocubes with high-index $\{h k 0\}$ facets and their enhanced electrocatalytic activities. Langmuir, 2012, 28: 14845-14848

48 Lim B, Jiang M, Camargo PHC, et al. Pd-Pt bimetallic nanodendrites with high activity for oxygen reduction. Science, 2009, 324: 1302-1305

49 Marković NM, Grgur BN, Ross PN. Temperature-dependent hydrogen electrochemistry on platinum low-index single-crystal surfaces in acid solutions. J Phys Chem B, 1997, 101: 5405-5413 
50 Bai S, Wang C, Deng M, et al. Surface polarization matters: enhancing the hydrogen-evolution reaction by shrinking Pt shells in Pt-Pd-graphene stack structures. Angew Chem Int Ed, 2014, 53: 12120-12124

Acknowledgements This work was supported by the Ministry of Education under AcRF Tier 2 (ARC 19/15, No. MOE2014-T2-2-093; MOE2015-T2-2-057; MOE2016-T2-2-103; MOE2017-T2-1-162) and AcRF Tier 1 (2016-T1-001-147; 2016-T1-002-051; 2017-T1-001-150; 2017-T1-002-119), and Nanyang Technological University under StartUp Grant (M4081296.070.500000) in Singapore. We would like to acknowledge the Facility for Analysis, Characterization, Testing and Simulation, Nanyang Technological University, Singapore, for use of their electron microscopy (and/or X-ray) facilities.

Author contributions All authors contributed to the discussion and preparation of the manuscript. The final version of the manuscript was approved by all authors.

Conflict of interest The authors declare that they have no conflict of interest.

Supplementary information Supporting figures and calibration curve of $\mathrm{Ag} / \mathrm{AgCl}\left(3 \mathrm{~mol} \mathrm{~L}^{-1} \mathrm{KCl}\right)$ reference electrode are available in the online version of the paper.

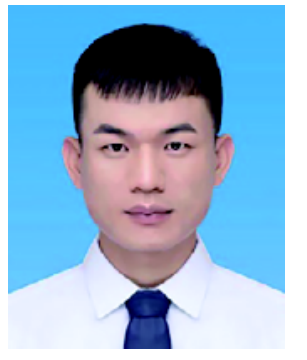

Zhimin Luo is currently a professor at Institute of Advanced Materials (IAM), Nanjing University of Posts and Telecommunications. He received his bachelor degree from Fujian Normal University in 2002 and completed his PhD in 2013 under the supervision of Prof. Lianhui Wang. He worked as a postdoctoral fellow in Prof. Hua Zhang's group in the School of Materials Science and Engineering at Nanyang Technological University in Singapore from 2013 to 2018. His research interests include the synthesis and applications of advanced catalysts such as two-dimensional metal dichalcogenides and noble metal nanostructures.

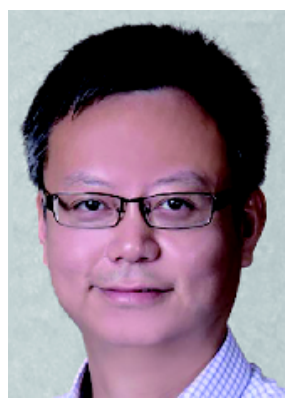

Hua Zhang obtained his bachelor and master degrees at Nanjing University in 1992 and 1995, respectively, and completed his PhD with Prof. Zhongfan Liu at Peking University in 1998. As a Postdoctoral Fellow, he joined Prof. Frans C. De Schryver's group at Katholieke Universiteit Leuven (Belgium) in 1999, and then moved to Prof. Chad A. Mirkin's group at Northwestern University in 2001. After he worked at NanoInk Inc. (USA) and Institute of Bioengineering and Nanotechnology (Singapore), he joined Nanyang Technological University in July 2006. His current research interests focus on the the (crystal-)phase engineering of nanomaterials and controlled epitaxial growth of heterostructures, including the synthesis of ultrathin two-dimensional nanomaterials (e.g. metal nanosheets, graphene, metal dichalcogenides, metal-organic frameworks, covalent organic frameworks, etc.), novel metallic and semiconducting nanomaterials, novel amorphous nanomaterials and their hybrid composites, for various applications such as catalysis, clean energy, (opto-)electronic devices, nano- and biosensors, and water remediation.

\section{电化学方法把铂丝转化到碳布上形成铂二十面体和纳米立方体并用于电催化产氢}

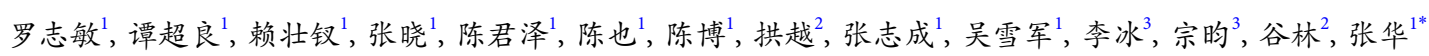

摘要 湿化学法可控合成贵金属纳米结构通常需要金属盐或金属配合物作为前体, 并利用表面活性剂和配体来调节和稳定纳米结构的形 貌. 本文通过一种简单的电化学方法(线性扫描伏安法), 在三电极体系中直接把铂线转化到碳布表面形成铂二十面体和纳米立方体. 在三 电极体系中, 铂线、碳布和 $\mathrm{Ag} / \mathrm{AgCl}\left(3 \mathrm{~mol} \mathrm{~L} \mathrm{~L}^{-1} \mathrm{KCl}\right)$ 分别作为对电极、工作电极和参比电极. 与商业 $\mathrm{Pt} / \mathrm{C}$ 催化剂相比, 制备的铂二十面体和 纳米立方体展现出优越的电催化活性. 该方法简单、有效, 可拓展到其他贵金属纳米结构的合成和应用研究. 如通过这种电化学方法直接 将 $\mathrm{Au} 、 \mathrm{Pd}$ 等块体材料转化成具有各种潜在应用的 $\mathrm{Au} 、 \mathrm{Pd}$ 等纳米结构. 